Article

\title{
Adaptation and Validation of the Prosocial and Antisocial Behavior Scale in Sports for the Spanish Context
}

\author{
Noelia Navarro ${ }^{1}$, Rubén Trigueros ${ }^{2, *}$, Adolfo J. Cangas ${ }^{1, *}$ and José M. Aguilar-Parra ${ }^{2}$ \\ 1 Department of Psychology, Hum-760 Research Team, Health Research Centre, University of Almería, \\ 04120 Almería, Spain; nng777@ual.es \\ 2 Department of Psychology, Hum-878 Research Team, Health Research Centre, University of Almería, \\ 04120 Almería, Spain; jmaguilar@ual.es \\ * Correspondence: rtr088@ual.es (R.T.); ajcangas@ual.es (A.J.C.)
}

Received: 5 February 2020; Accepted: 30 March 2020; Published: 3 April 2020

\begin{abstract}
The sporting context favors exchange and promotes social relations. Although there are various tools for measuring social behavior, most of them are not adapted to the Spanish context. The aim of the present study was to adapt and validate the Scale of Prosocial and Antisocial Behavior in Sports (PABSS) for that context. The sample was made up of 732 athletes between the ages of 18 and $38(\mathrm{M}=22.9 ; \mathrm{SD}=7.3)$. Statistical analyses allowed us to confirm their appropriate psychometric properties. Exploratory factor analysis revealed the existence of two factors (antisocial behavior and prosocial behavior). The results of the confirmatory factor analysis supported the internal structure of the questionnaire. In addition, the scale was invariant with respect to gender. Cronbach's Alpha values above 0.70 were found in the different subscales, as well as adequate temporal stability. Therefore, the scale provides a very useful tool in clarifying behavioral processes at the base of prosocial and antisocial behavior in adults towards teammates or rivals in the context of sports competitions in Spain.
\end{abstract}

Keywords: social behavior; athletes; validation; sport

\section{Introduction}

In the field of sport, prosocial behavior and values promote moral and social development, commitment, participation, and the transmission of values such as cooperation, tolerance, respect for rules, and self-discipline, are continuously generated [1,2]. However, participation in sports is also associated with negative outcomes, mainly due to its competitive nature and excessive pressure to win, which can lead to antisocial and unsportsmanlike behavior. Sometimes the result is aggressive and violent behavior, an excessive desire to win, and other socially undesirable qualities [3]. For this reason, Kavussanu and Boardley [2] created the Scale of Prosocial and Antisocial Behavior in Sports to measure such behaviors in the sports context, a scale that has been successfully applied in multiple studies $[4,5]$. In the Spanish context, there are currently no instruments for assessing prosocial and antisocial behavior in sport.

Prosocial behavior can be defined as "the set of actions that aim to benefit other people or groups" [6]. This type of behavior has been described as voluntary and multi-causal, determined by a great diversity of causal and experiential factors, as well as moderating processes and circumstances of socialization effects [7]. In this sense, most research has focused on adolescent behaviors and less on sports. Studies suggest that prosocial behavior plays an important role in establishing positive interpersonal relationships [8,9], in motivation and academic success [10], and in meeting 
psychological needs [11]. In sports contexts, this type of behavior would be represented in actions such as congratulating the opposing team after a win, cooperating in team strategy, or apologizing for a bad action. In this way, prosocial behavior would encourage the establishment of social bonds, protecting or moderating maladaptive styles of social interaction, such as aggression, isolation, or social withdrawal [6,12]. A higher frequency of prosocial behaviors and a lower frequency of antisocial behaviors have also been found when the recipient of such actions is a teammate than when he or she is an opponent $[13,14]$. In addition, those athletes who experience more prosocial behavior toward their teammates have been found to have more prosocial behavior toward others as well [15].

On the opposite side, antisocial behavior would be found, which refers to acts that violate social norms and the rights of others [16]. In the area of team sports, these would be represented by actions such as pushing, cheating, or faking a fall or injury in a way that causes harm or injury to others, with the intention of achieving negative consequences [17]. It has been shown that variables such as the nature of the sport (individual or collective) would influence this type of manifestation, with higher levels of aggressiveness found in collective sports [18]. In addition, the inherent characteristics of each sport modify the type of antisocial behavior that occurs. Thus, in table tennis, swimming, and shooting, antisocial behavior is more verbal and psychological, while in sports such as karate and basketball, antisocial manifestations are mainly of a physically aggressive nature [19]. The level of competition is another variable traditionally related to antisocial behavior, finding that as the level of competition increases, players feel more "empowered" to engage in such behavior [20]. In terms of the relationship with other variables of a more psychological nature, antisocial behavior has been associated with poorer outcomes in temperament, cognitive ability, peer group relationships, and general social adjustment [21]. Similarly, it is negatively correlated with academic performance [22] and study motivation [23].

Prosocial and antisocial behavior, therefore, would represent two opposing dimensions in sports morality [24]. In this sense, studies on prosocial and antisocial behavior have focused mainly on competitive and school sports contexts. More specifically, research points to a higher frequency and intensity of antisocial behavior compared to prosocial behavior $[25,26]$. With regard to the evaluation of these antagonistic dimensions, it is convenient to focus on the behavioral component [27], that is, the concrete materialization of prosocial or antisocial behavior in concrete situations. Behavior has more weight than beliefs (cognitions), feelings, or emotions (affects), and there may also be a discrepancy between these three response systems. For example, a person may have a strong belief that "pushing the other person is wrong", but in a stressful situation during a competition, the person may be unable to control their impulses and end up attacking the opponent.

Among the instruments for assessing prosocial and antisocial behavior are the Prosocial Tendencies Measure by Carlo and Randall [26], the Prosocialness Scale for Adults by Caprara, Steca, Zelli, and Capanna [28], and the Antisocial and Criminal Behavior Scale [29]. However, these scales have the limitation that they only take into account one of the measures of social behavior, discarding the others. For this reason, Inderbitzen and Foster [30] developed the Teenage Inventory of Social Skills (TISS), which combines both dimensions in the two subscales that comprise it, assessing the prosocial and antisocial behaviors of adolescents in their relationships with their peers. This scale is composed of 40 items that are distributed between two separate scores. Regarding the psychometric properties of this instrument, there is a reliability of 0.90 for the prosocial scale and 0.72 for the antisocial scale [30]; the correlation between both factors is -0.26 . Based on this last scale, Kavussanu and Boardley [2] developed the Prosocial and Antisocial Behavior in Sports Scale (PABSS) for the sports context in order to evaluate the social and antisocial behaviors of the athletes. For this purpose, they carried out a study in which 1213 athletes from various sports participated, these participants having an average age of 21.97 years. The original questionnaire was made up of 30 items distributed among four sub-factors, and these in turn between two factors. In order for the instrument to have a good factorial structure, an exploratory and confirmatory factorial analysis was performed (see [2]), eliminating those items whose standardized weight was lower than 0.30 , forming a final questionnaire of 20 items. The authors 
also performed a reliability analysis that revealed that each of the factors and sub-factors was above 0.70 . Finally, gender invariance analysis revealed that the questionnaire was similarly understood by athletes.

Due to the absence of instruments to assess prosocial and antisocial behaviors in the Spanish context, the aim of this study is to adapt and validate the Kavussanu and Boardley Scale of Prosocial and Antisocial Behavior in Sports [2]. In this way, it is expected to be a valid and reliable instrument to measure such behavior in the Spanish sports environment.

\section{Methods}

\subsection{Participants}

The participants in the present study were divided into three independent samples (see Table 1), belonging to several sports clubs in Andalusia (Spain). The selection of the sample was non-probabilistic and incidental, based on the sports clubs we had access to and the athletes who wanted to participate. Likewise, the provision of informed consent was the criterion for participation in the study.

Table 1. Participants in the study.

\begin{tabular}{|c|c|c|c|c|}
\hline & $\begin{array}{l}\text { Mean Age (Standard } \\
\text { Deviation) }\end{array}$ & $\begin{array}{l}\text { Distribution } \\
\text { Sample }\end{array}$ & Type of Sports & Age Range \\
\hline $\begin{array}{l}\text { Confirmatory } \\
\text { factor and } \\
\text { descriptive analysis }\end{array}$ & $22.9(\mathrm{SD}=7.3)$ & $\begin{array}{c}387 \text { Men and } 345 \\
\text { Women } \\
\mathrm{N}=732\end{array}$ & $\begin{array}{c}\text { Basketball: } 132 \text { Men and } 128 \\
\text { Women } \\
\text { Handball: } 98 \text { Men and } 74 \\
\text { Women } \\
\text { Athletics (Track and Field): } \\
76 \text { Men and } 46 \text { Women } \\
\text { Volleyball: } 81 \text { Men and } 97 \\
\text { Women }\end{array}$ & $18-38$ \\
\hline $\begin{array}{l}\text { Exploratory Factor } \\
\text { Analysis }\end{array}$ & $21.4(\mathrm{SD}=6.1)$ & $\begin{array}{c}246 \text { Men and } 222 \\
\text { Women } \\
\mathrm{N}=468\end{array}$ & $\begin{array}{c}\text { Basketball: } 72 \text { Men and } 65 \\
\text { Women } \\
\text { Handball: } 57 \text { Men and } 51 \\
\text { Women } \\
\text { Athletics (Track and Field): } \\
63 \text { Men and } 56 \text { Women } \\
\text { Volleyball: } 54 \text { Men and } 50 \\
\text { Women }\end{array}$ & $18-33$ \\
\hline $\begin{array}{c}\text { Temporal Stability } \\
\text { Analysis }\end{array}$ & $24.5(\mathrm{SD}=7.3)$ & $\begin{array}{l}113 \text { Men and } 127 \\
\text { Women } \\
\mathrm{N}=240\end{array}$ & $\begin{array}{c}\text { Basketball: } 25 \text { Men and } 22 \\
\text { Women } \\
\text { Handball: } 31 \text { Men and } 51 \\
\text { Women } \\
\text { Athletics (Track and Field): } \\
33 \text { Men and } 32 \text { Women } \\
\text { Volleyball: } 24 \text { Men and } 22 \\
\text { Women }\end{array}$ & $19-36$ \\
\hline
\end{tabular}

\subsection{Instruments}

To assess prosocial and antisocial behavior in the sports context, the Kavussanu and Boardley Prosocial and Antisocial Behavior in Sports Scale (PABSS) was adapted to and validated for the Spanish context [2]. The scale is composed of four sub-factors that are divided into two factors: Prosocial behavior (towards teammates, 4 items; towards opponents, 3 items) and antisocial behavior (towards teammates, 5 items; towards opponents, 8 items). The athletes had to respond through a scale ranging from 1 , which refers to strongly disagreeing, to 7 , strongly agreeing.

\subsection{Procedure}

The first step to validate the questionnaire is to translate the scale into the Spanish context, following the Hambleton procedure [31]. This strategy consists of the translation of the original scale into Spanish by a group of translators. Later, another group of translators translated the scale from 
Spanish into the original language of the scale. Each of the translators has more than 10 years of experience in translating manuscripts related to sports psychology. The quality of the translation was considered in relation to the coincidence with the original version.

Each one of the items of the final scale was analyzed by three expert researchers in the field of sports psychology with extensive experience so as to ensure that the items of the scale were well designed to measure the variables to be measured without losing the meaning of the original scale. Once the final scale was obtained, we contacted the sports clubs to present the scale, informing them of the objectives we intended to achieve with the study and requesting their permission and collaboration. Once the permission was obtained, the athletes were contacted, were asked to participate, and were informed of the objective of the study. In addition, they were required to give their informed consent in order to participate in the study. A member of the research group was present while the participants filled out the questionnaires, in case there was any doubt during their completion. The participants took about 15 minutes to fill out the scale.

This research has been approved by the Bioethics Committee of the University of Almeria (Ref. UALBIO 2019/014). In addition, the ethical principles established by the American Psychological Association and in accordance with the Declaration of Helsinki were respected at all times.

\subsection{Data Analysis}

The PABSS scale was psychometrically examined to check its reliability and validity in the Spanish sports context. Initially, the factor structure of the questionnaire was analyzed through an exploratory factor analysis (EFA). Then, the factor structure was analyzed again through a confirmatory factor analysis (CFA), and, finally, the invariance of the instrument was analyzed through a multi-group analysis in order to know if the scale was understood in a similar way by male and female athletes. On the other hand, descriptive statistics, internal consistency, and temporal stability were analyzed. The statistical packages SPSS 25 and AMOS 20 were used.

The Mardia coefficient was very high (122.54) after the CFA, so the maximum likelihood estimation method was used along with the bootstrapping procedure. The estimators were not affected by the lack of normality and were therefore considered robust [32]. Hair, Black, Babin, Anderson, and Tatham adjustment rates were taken into consideration [33] in order to be able to accept or reject the model tested (Table 2):

Table 2. Model fitting rates.

\begin{tabular}{cc}
\hline & Adjustment Rates \\
\hline NFI (Normed Fit Index) & $\geq 0.95$ \\
Comparative Fit Index (CFI) & $\geq 0.95$ \\
Tucker-Lewis Index (TLI) & \\
Incremental Fit Index (IFI) & $\leq 0.06$ \\
Root Mean Square Error of Approximation (RMSEA) & $\leq 0.06$ \\
Standardized Root Mean Square Residual (SRMR) & \\
\hline
\end{tabular}

\section{Results}

\subsection{Exploratory Factor Analysis}

Firstly, an EFA was carried out using the main components with the 20 items that make up the scale. The results showed two components with eigenvalues greater than 1 , which explained $42.48 \%$ and $56.17 \%$ of the variance in the total score, respectively.

Furthermore, Table 3 shows how the exploratory factor analysis supports the existence of two factors, with a saturation factor ranging from 0.76 to 0.85 for prosocial behavior and from 0.76 to 0.83 for antisocial behavior. In addition, the correlations between each of the items and the overall scale score range from 0.78 to 0.85 , which is acceptable according to Fayers and Machin [34]. 
Table 3. Correlations between each item and the total scale score; reliability.

\begin{tabular}{ccc}
\hline Items & Correlations Item-Test & $\begin{array}{c}\text { Saturation Factor of Each Item } \\
\text { with its Factor }\end{array}$ \\
\hline 1 & $0.82^{* *}$ & $0.82 \mathrm{~PB}$ \\
2 & $0.83^{* *}$ & $0.83 \mathrm{~PB}$ \\
3 & $0.84^{* *}$ & $0.77 \mathrm{~PB}$ \\
4 & $0.80^{* *}$ & $0.78 \mathrm{~PB}$ \\
5 & $0.85^{* *}$ & $0.80 \mathrm{~PB}$ \\
6 & $0.84^{* *}$ & $0.79 \mathrm{~PB}$ \\
7 & $0.83^{* *}$ & $0.75 \mathrm{~PB}$ \\
8 & $0.82^{* *}$ & $0.83 \mathrm{AB}$ \\
9 & $0.81^{* *}$ & $0.81 \mathrm{AB}$ \\
10 & $0.80^{* *}$ & $0.79 \mathrm{AB}$ \\
11 & $0.85^{* *}$ & $0.76 \mathrm{AB}$ \\
12 & $0.80^{* *}$ & $0.77 \mathrm{AB}$ \\
13 & $0.83^{* *}$ & $0.79 \mathrm{AB}$ \\
14 & $0.81^{* *}$ & $0.84 \mathrm{AB}$ \\
15 & $0.82^{* *}$ & $0.83 \mathrm{AB}$ \\
16 & $0.84^{* *}$ & $0.85 \mathrm{AB}$ \\
18 & $0.80^{* *}$ & $0.81 \mathrm{AB}$ \\
19 & $0.84^{* *}$ & $0.79 \mathrm{AB}$ \\
20 & $0.80^{* *}$ & $0.83 \mathrm{AB}$ \\
\hline & $0.83^{* *}$ & $0.84 \mathrm{AB}$ \\
\hline$<0.01 \mathrm{Note}: \mathrm{AB}=$ antisocial behavior $\mathrm{PB}=$ prosocial behavior
\end{tabular}

\subsection{Confirmatory Factor Analysis}

The model values tested (Figure 1) revealed appropriate fit rates: comparative fit index $(\mathrm{CFI})=0.97$; incremental fit index (IFI) $=0.97$; Tucker-Lewis index $(\mathrm{TLI})=0.97$; normed fit index (NFI) = 0.97; standardized root mean square residual $(\mathrm{SRMR})=0.039$; root mean square error of approximation $($ RMSEA $)=0.057(90 \%$ confidence interval $(C I)=0.055-0.063)$. Standardized regression weights ranged from 0.73 to 0.86 and were statistically significant $(p<0.001)$. The correlation between the factors was -0.58 , which is statistically significant $(p<0.01)$. 


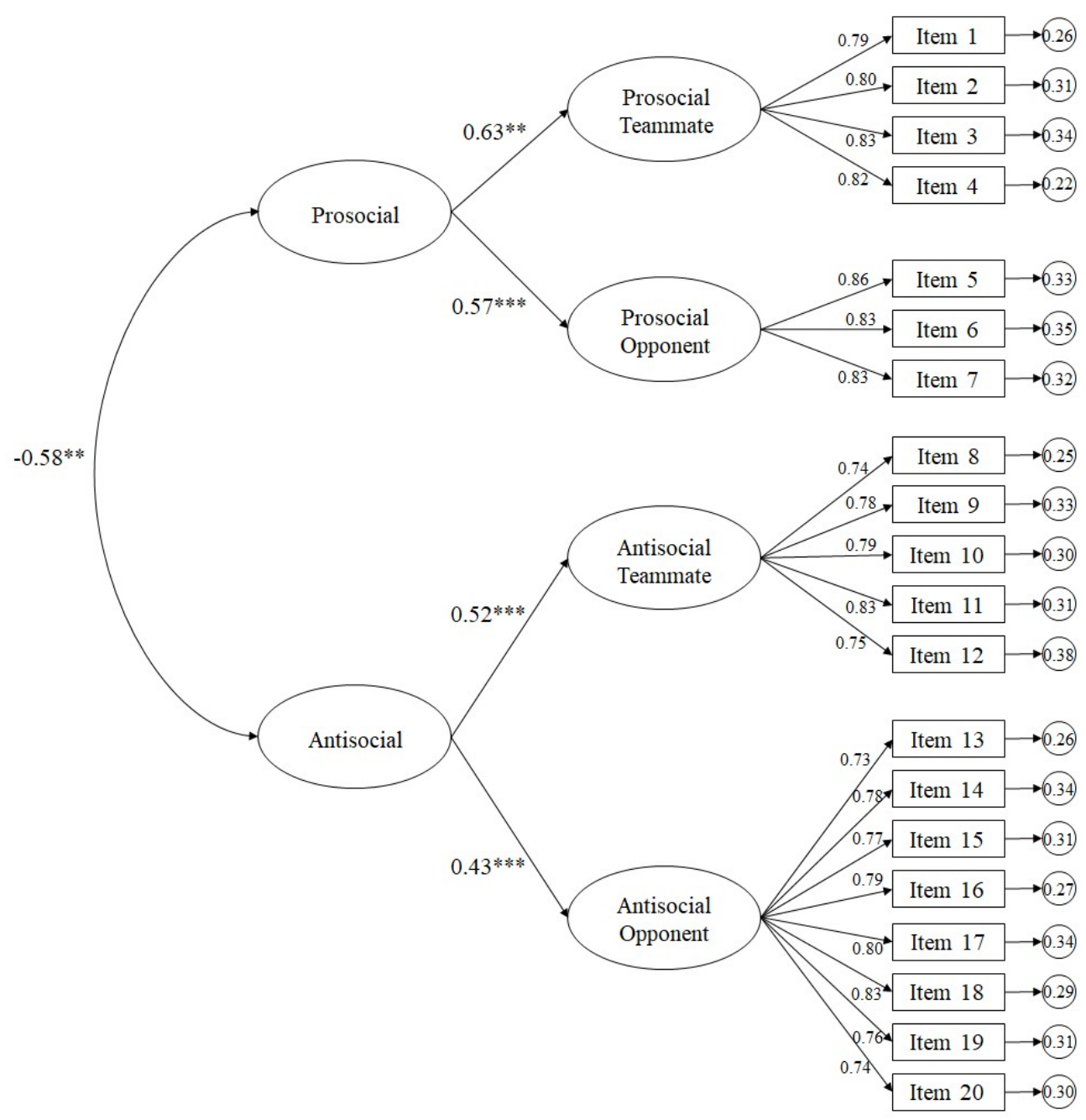

Figure 1. Confirmatory factorial analysis. The ellipses represent the factors and the rectangles represent the different items. Residual variances are shown in small circles. ${ }^{* * *} p<0.001 ;{ }^{* *} p<0.01$

\subsection{Gender Invariance Analysis}

The results of the multi-group analysis are shown in Table 4. These analyses are aimed at demonstrating whether the factor structure of the scale is invariant to the gender. As shown in the table, there is an absence of significant differences between the unrestricted model (Model 1) and the models of invariance in the measurement weights (Model 2) and structural weights (Model 3). On the other hand, the results did show significant differences between Model 1 and the models of invariant structural covariances (Model 4), of structural waste (Model 5), and of invariant measure waste (Model 6).

Table 4. Gender invariance analysis.

\begin{tabular}{|c|c|c|c|c|c|c|c|c|c|c|}
\hline Models & $x^{2}$ & $d f$ & $x^{2} / d f$ & $\Delta \chi^{2}$ & $\Delta d f$ & CFI & TLI & IFI & RMSEA (IC 90\%) & SRMR \\
\hline Model 1 & 1029.61 & 330 & 3.12 & - & - & 0.97 & 0.96 & 0.97 & $0.055(0.048-0.062)$ & 0.042 \\
\hline Model 2 & 1087.74 & 346 & 3.14 & 17.63 & 16 & 0.97 & 0.96 & 0.97 & $0.058(0.053-0.062)$ & 0.044 \\
\hline Model 3 & 1125.47 & 348 & 3.23 & 21.42 & 18 & 0.97 & 0.96 & 0.97 & $0.062(0.057-0.065)$ & 0.046 \\
\hline Model 4 & 1145.47 & 351 & 3.26 & $28.88^{*}$ & 21 & 0.96 & 0.96 & 0.96 & $0.062(0.058-0.065)$ & 0.047 \\
\hline Model 5 & 1175.93 & 355 & 3.31 & $41.32 *$ & 25 & 0.96 & 0.95 & 0.96 & $0.062(0.059-0.064)$ & 0.047 \\
\hline Model 6 & 1291.30 & 375 & 3.44 & $85.42 * * *$ & 45 & 0.95 & 0.95 & 0.95 & $0.064(0.059-0.066)$ & 0.052 \\
\hline
\end{tabular}


To accept that the model is gender invariant, the minimum criterion is the absence of significant differences between Model 1 and Model 2 [35].

\subsection{Descriptive Statistics, Correlation, and Reliability Analysis}

Correlations between the two factors on the scale show a negative valence, making a clear lack of negative reciprocity between the two manifest (Table 5). On the other hand, the factors and sub-factors that make up the scale show clear evidence of reliability through Cronbach's Alpha with scores above 0.70 [36]. Finally, the analysis of temporal stability through the intra-class correlation coefficients (ICC) and their confidence intervals $(\mathrm{CI})$, showed a score of $0.83(\mathrm{CI}=0.80-0.86)$ for antisocial behavior and $0.85(\mathrm{CI}=0.82-0.88)$ for prosocial behavior.

Table 5. Descriptive statistics and bivariate correlations.

\begin{tabular}{|c|c|c|c|c|c|c|c|c|c|c|}
\hline Factors & $M$ & $S D$ & $\alpha$ & Range & 1 & 1.1 & 1.2 & 2 & 2.1 & 2.2 \\
\hline 1. Prosocial & 5.1 & 1.02 & 0.83 & $1-7$ & & $0.51 * *$ & 0.39 ** & $-0.38^{* *}$ & $-0.53^{* * *}$ & $-0.44^{* * *}$ \\
\hline 1.1. Teammate & 5.3 & 0.91 & 0.86 & $1-7$ & & & $0.47^{* *}$ & $-0.32 * * *$ & $-0.61^{* * *}$ & $-0.56^{* *}$ \\
\hline 1.2. Opponent & 4.9 & 0.83 & 0.80 & $1-7$ & & & & $-0.43 * *$ & $-0.35^{* *}$ & $-0.68^{* * *}$ \\
\hline 2. Antisocial & 2.0 & 1.11 & 0.81 & $1-7$ & & & & & $0.36^{* * *}$ & $0.40^{* *}$ \\
\hline 2.1. Teammate & 2.1 & 1.20 & 0.80 & $1-7$ & & & & & & $0.49^{* * *}$ \\
\hline 2.2. Opponent & 1.9 & 0.89 & 0.83 & $1-7$ & & & & & & \\
\hline
\end{tabular}

\section{Discussion}

The aim of this study was to analyze the psychometric properties of the adaptation to the Spanish context of the Prosocial and Antisocial Behavior Sports Scale of Kavussanu and Boardley [2] in order to determine its validity and reliability. The findings have determined that it is a reliable, valid, and invariant instrument for analyzing the prosocial and antisocial behaviors of athletes in a sports context.

The results reached in the present study through the EFA in first place and by the CFA in second place have shown that the scale is made up of two factors and four sub-factors. In this sense, the CFA has shown that the two-factor structure is supported by the four sub-factors. These results are similar to those of the original scale, where Kavussanu and Boardley [2], through EFA and CFA, showed results similar to those of the present study. As for the multi-group analysis, it showed that the factor structure of the instrument was invariant with respect to sex due to the existence of significant differences between Model 1 and Model 4. These results are similar to those of the original scale, where Kavussanu and Boardley [2] evidenced that their questionnaire was understood in a similar way by athletes, regardless of their sex. In this way, the questionnaire will allow the establishment of comparisons between male and female athletes in future studies in order to be able to determine differences between populations.

Reliability analyses using Cronbach's Alpha reflected an adequate score as well as the original scale [2]. On the other hand, the temporal stability analysis revealed that after two weeks, the athletes understood the items of the questionnaire in a similar way, so this will allow the researchers to carry out longitudinal studies comparing the prosocial and antisocial behaviors of the athletes over time. These results cannot be compared with the original study, as the authors did not consider this latter analysis. Finally, the bivariate correlations between the factors (and sub-factors) reflected the same valence as in the CFA. These results are similar to those of the original scale. Therefore, it is possible to establish that the scale has an adequate discriminant validity.

Following the results achieved in this study, coaches and trainers have an effective tool with which to evaluate the social and antisocial behaviors of their athletes. However, it is necessary to highlight the following limitations. First of all, this adaptation is conditioned by the very specific socio-cultural context in which it has been validated. Secondly, with regard to age groups, only a very restricted range has been taken into account, limited to active athletes. 
In this sense, it would be interesting if future studies would extend this age range, since there are sports such as chess, motorsports, cycling, race-walking, shooting, etc. whose participants can extend their sporting lives beyond the age of 40 . Furthermore, future studies could analyze how the narcissistic personalities of elite athletes influence their antisocial behaviors and team climates. In this sense, the recent study by Jones, Woodman, Barlow, and Roberts [37] suggests that the narcissistic behavior of athletes is a reason for the generation of antisocial behavior during competition or training. Similarly, future studies could also consider the influence of emotional intelligence as a protective factor against maladaptive behaviors [38] and its influence on prosocial and antisocial behaviors.

For all of these reasons, the Scale of Prosocial and Antisocial Behavior in Sports in the Spanish context can be considered a tool that can be used by sports coaches and the community in general. The scale contributes significantly to the clarification of the behavioral processes of the athlete towards his/her peers (members of the same group or rivals). It can also contribute to the healthy and integral development of the athlete by working on values and moral issues [12] and promoting the development of social skills [39], mutual respect, cooperation, and tolerance [40].

\section{Conclusions}

This study provides evidence that allows us to consider the PABSS as a valid and reliable instrument for measuring prosocial and antisocial behaviors in the Spanish sports context (Appendix A).

Author Contributions: Conceptualization, R.T.; methodology, R.T. and J.M.A.-P.; validation, N.N. and A.J.C.; formal analysis, R.T. and J.M.A.-P.; data curation, N.N.; writing-original draft preparation, R.T.; writing-review and editing, A.J.C. and J.M.A.-P.; project administration, A.J.C.; funding acquisition, A.J.C. All authors have read and agreed to the published version of the manuscript.

Funding: This research received no external funding.

Conflicts of Interest: The authors declare no conflict of interest.

\section{Appendix A}

1. Encouraged a teammate Animo a un compañero de equipo

2. Congratulated a teammate for good play Felicito a un compañero de equipo por su buen juego

3. Gave positive feedback to a teammate Doy una respuesta positiva a un compañero de equipo

4. Gave constructive feedback to a teammate Le doy retroalimentación constructiva a un compañero de equipo

5. Helped an injured opponent Ayudo a un oponente lesionado

6. Asked to stop play when an opponent was injured Pido que detuviera el juego cuando un oponente se lesionó

7. Helped an opponent off the floor Ayudo a un oponente a levantarse del suelo

8. Verbally abused a teammate Insulto a un compañero de equipo

9. Swore at a teammate Maldigo a un compañero de equipo

10. Argued with a teammate Discuto con un compañero de equipo

11. Criticized a teammate Critico a un compañero de equipo

12. Showed frustration at a teammate's poor play Me enfado por el mal juego de un compañero de equipo

13. Tried to injure an opponent Trato de herir a un oponente

14. Tried to wind up an opponent Trato de acabar con un oponente

15. Deliberately fouled an opponent Deliberadamente engañó a un oponente.

16. Intentionally distracted an opponent Distrajo intencionalmente a un oponente.

17. Retaliated after a bad foul Tomo represalias después de una mala falta.

18. Intentionally broke the rules of the game Rompo intencionalmente las reglas del juego

19. Physically intimidated an opponent Intimido físicamente a los oponentes 
20. Criticized an opponent Critico a los oponentes

\section{References}

1. Hodge, K.; Lonsdale, C. Prosocial and antisocial behavior in sport: The role of coaching style, autonomous vs. controlled motivation, and moral disengagement. J. Sport Exerc. Psychol. 2011, 4, 527-547. [CrossRef]

2. Kavussanu, M.; Boardley, I. The Prosocial and Antisocial Behavior in Sport Scale. J. Sport Exerc. Psychol. 2009, 1, 97-117. [CrossRef]

3. Li, C.; Koh, K.T.; Keng, C.; Wang, J.; Chian, L.K. Sports participation and moral development outcomes: Examination of validity and reliability of the prosocial and antisocial behavior in sport scale. Int. J. Sports Sci. Coach. 2015, 2, 505-513. [CrossRef]

4. Boardley, I.D.; Kavussanu, M. The influence of social variables and moral disengagement on prosocial and antisocial behaviours in field hockey and netball. J. Sports Sci. 2009, 8, 843-854. [CrossRef] [PubMed]

5. Bruner, M.W.; Boardley, I.D.; Benson, A.J.; Wilson, K.S.; Root, Z.; Turnnidge, J.; Sutcliffe, J.; Côté, J. Disentangling the relations between social identity and prosocial and antisocial behavior in competitive youth sport. J. Youth Adolesc. 2018, 5, 1113-1127. [CrossRef] [PubMed]

6. Martí-Vilar, M.; Serrano-Pastor, L.; González-Sala, F. Emotional, cultural and cognitive variables of prosocial behaviour. Curr. Psychol. 2019, 1-8. [CrossRef]

7. Eisenberg, N.; Fabes, R.A.; Spinrad, T.L. Prosocial development. In Handbook of Child Psychology, Vol. 3: Social, Emotional and Personality Development; Damon, W., Eisenberg, N., Eds.; John Wiley \& Sons: New York, NY, USA, 2006; pp. 646-718.

8. Meece, J.L.; Anderman, E.M.; Anderman, L.H. Classroom goal structure, student motivation, and academic achievement. Annu. Rev. Psychol. 2006, 57, 487-503. [CrossRef]

9. Wentzel, K.R. Peer relationships, motivation, and academic performance at school. In Handbook of Competence and Motivation; Elliot, J., Dweck, C.S., Eds.; Guilford Press: New York, NY, USA, 2005; pp. 279-296.

10. Nicosia, N.; Wong, E.; Shier, V.; Massachi, S.; Datar, A. Parental deployment, adolescent academic and social-behavioral maladjustment, and parental psychological well-being in military families. Public Health Rep. 2017, 1, 93-105. [CrossRef]

11. Kuzucu, Y.; Şimşek, Ö.F. Self-determined choices and consequences: The relationship between basic psychological needs satisfactions and aggression in late adolescents. J. Gen. Psychol. 2013, 2, 110-129. [CrossRef]

12. Inglés, C.J.; Martínez- González, A.; García-Fernández, J.M. Conducta prosocial y estrategias de aprendizaje en una muestra de estudiantes españoles de Educación Secundaria Obligatoria. Eur. J. Educ. Psychol. 2013, 1, 33-53. [CrossRef]

13. Bruner, M.W.; Eys, M.A.; Wilson, K.S.; Côté, J. Group cohesión and positive youth development in team sport athletes. Sport Exerc. Perform. Psychol. 2014, 4, 219-227. [CrossRef]

14. Baek, S.Y.; Lee, K. Association among cultural orientation, Nunchi, and interpersonal relationships with korean adolescent athletes. Revista de Psicología del Deporte 2019, 2, 67-78.

15. Benson, A.J.; Bruner, M.W. How teammate behaviors relate to athlete affect, cognition, and behaviors: A daily diary approach within youth sport. Psychol. Sport Exerc. 2018, 34, 119-127. [CrossRef]

16. Peña-Fernández, M.E.; Graña-Gómez, J.L. Agresión y Conducta Antisocial en la adolescencia: Una integración conceptual. Psicopatología Clínica legal y Forense 2006, 6, 9-24.

17. Kavussanu, M. Motivational predictors of prosocial and antisocial behaviour in football. J. Sports Sci. 2006, 6, 575-588. [CrossRef] [PubMed]

18. Pelegrín, A.; Serpa, S.; Rosado, A. Aggressive and unsportsmanlike behaviours in competitive sports: An analysis of related personal and environmental variables. Anales de Psicología 2013, 3, 701-713.

19. Guilbert, S. Violence in sports and among sportsmen: A single or two-track issue? Aggress. Behav. 2006, 32, 231-240. [CrossRef]

20. Visek, A.; Watson, J. Ice hockey players' legitimacy of aggression and professionalization of attitudes. Sport Psychol. 2005, 19, 178-192. [CrossRef]

21. Arce, R.; Fariña, F.; Vázquez, M.J. Grado de competencia social y comportamientos ntisociales, delictivos y no delictivos en adolescentes. Revista Latinoamericana de Psicología 2011, 3, 473-486. 
22. Wentzel, K.R.; Caldwell, K. Friendships, peer acceptance, and group membership: Realtions to academic achievement in middle school. Child Dev. 1997, 6, 1198-1209.

23. Van Acker, R. Antisocial, aggressive, and violent behavior in children and adolescents within alternative education settings: Prevention and intervention. Prev. Sch. Fail. Altern. Educ. Child. Youth 2007, 2, 5-12. [CrossRef]

24. Kavussanu, M.; Stamp, R.; Slade, G.; Ring, C. Observed prosocial and antisocial behaviors in male and female soccer players. J. Appl. Sport Psychol. 2009, 21, 62-76. [CrossRef]

25. Boardley, I.D.; Jackson, B. When teammates are viewed as rivals: A cross-national investigation of achievement goals and intra team moral behavior. J. Sport Exerc. Psychol. 2012, 34, 503-524. [CrossRef]

26. Carlo, G.; Randall, B.A. The development of a measure of prosocial behaviors for late adolescents. J. Youth Adolesc. 2002, 31, 31-44. [CrossRef]

27. Bandura, A. Social cognitive theory of self-regulation. Organ. Behav. Hum. Decis. Process. 1991, 2, $248-287$. [CrossRef]

28. Caprara, G.V.; Steca, P.; Zelli, A.; Capanna, C. A new scale for measuring adults' prosocialness. Eur. J. Psychol. Assess. 2005, 2, 77-89. [CrossRef]

29. Andreu, J.M.; Peña, M.E. Propiedades psicométricas de la Escala de Conducta Antisocial y Delictiva en adolescentes. Anales de Psicología 2013, 2, 516-522.

30. Inderbitzen, H.M.; Foster, S.L. The Teenage Inventory of Social Skills: Development, reliability, and validity. Psychol. Assess. 1992, 4, 451-459. [CrossRef]

31. Hambleton, R.K. Adaptación de Tests para su uso en Diferentes Idiomas y Culturas: Fuentes de Error, Posibles Soluciones y Directrices Prácticas; Psicometría/Coord. por José Muñiz Fernández; Universitas: Madrid, Spain, 1996.

32. Byrne, B.M. Structural Equation Modeling with Amos: Basic Concepts, Applications and Programming; Erlbaum: Mahwah, NJ, USA, 2001.

33. Hair, J.F.; Black, W.C.; Babin, B.J.; Anderson, R.E.; Tatham, R.L. Multivarie Data Analysis; Pearson University: Upper Saddle River, NJ, USA, 2010.

34. Fayers, P.M.; Machin, D. Quality of Life: Assessment, Analysis and Interpretation; Wiley: Chichester, UK, 2000.

35. Marsh, H.W. The multidimensional structure of academic self-concept: Invariance over gender and age. Am. Educ. Res. J. 1993, 4, 841-860. [CrossRef]

36. Cicchetti, D.V.; Sparrow, S.A. Developing criteria for establishing interrater realibility for specific 284 items: Applications to assessment for adaptive behaviour. Am. J. Met. Defic. 1981, 2, 127-137.

37. Jones, B.D.; Woodman, T.; Barlow, M.; Roberts, R. The darker side of personality: Narcissism predicts moral disengagement and antisocial behavior in sport. Sport Psychol. 2017, 2, 109-116. [CrossRef]

38. Mikolajczak, M.; Menil, C.; Luminet, O. Explaining the protective effect of trait emotional intelligence regarding occupational stress: Exploration of emotional labour processes. J. Res. Personal. 2007, 5, 1107-1117. [CrossRef]

39. Samalot-Rivera, A.; Porretta, D. The influence of social skills instruction on sport and game related behaviours of students with emotional or behavioural disorders. Phys. Educ. Sport Pedagog. 2013, 18, 117-132. [CrossRef]

40. Bailey, R. Physical education and sport in schools: A review of benefits and outcomes. J. Sch. Health 2006, 76, 397-401. [CrossRef] [PubMed]

(C) 2020 by the authors. Licensee MDPI, Basel, Switzerland. This article is an open access article distributed under the terms and conditions of the Creative Commons Attribution (CC BY) license (http://creativecommons.org/licenses/by/4.0/). 